\title{
Lawsuits in health: an integrative review
}

\author{
Ações judiciais em saúde: revisão integrativa \\ Acciones judiciales en salud: revisión integrativa
}

Paula Mestre Ferreira Batistella'
ORCID: 0000-0003-2593-710X
Patrícia Aroni'
ORCID: 0000-0001-5092-2714

Alex Luís Fagundes'

ORCID: 0000-0003-3369-1197

Maria do Carmo Fernandez Lourenço Haddad' ORCID: 0000-0001-7564-8563

'Universidade Estadual de Londrina. Londrina, Paraná, Brasil.

How to cite this article:

Batistella PMF, Aroni P, Fagundes AL, Haddad MCFL.

Lawsuits in health: an integrative review.

Rev Bras Enferm [Internet]. 2019;72(1):809-17.

doi: http://dx.doi.org/10.1590/0034-7167-2018-0551

Corresponding Author:

Paula Mestre Ferreira Batistella

E-mail: paulamestrebatistella@hotmail.com

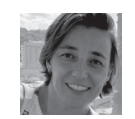

Submission: 07-12-2018 Approval: 01-30-2019

\section{ABSTRACT}

Objective: To analyze the national and international scientific evidence available in the literature on types of judicialization of health lawsuits. Method: Integrative review, which selected primary studies in the PubMed, LILACS, Web of Science and Scopus databases, with the Descriptors: judicial decisions, health's judicialization, Saúde (in Portuguese), Health, and the keyword: Judicial Action. Results: 30 studies were selected. In Brazil, the majority were legal claims for medicines and the other for medical errors, requests for vaccines, supplies for diabetics, food compounds, surgical procedure, examinations, among others. In international studies, lawsuits were found for medication, benefit coverage and hospitalization for psychiatric treatment. Conclusion: It is evident that the most demanded type of lawsuit was access to the medication at an international level. It is still more noticeable the little discussion on this subject, demonstrating that judicialization of medicines can indicate a reality of Brazil.

Descriptors: Health's Judicialization; Judicial Decisions; Health; Right to Health; Public Health Policy.

\section{RESUMO}

Objetivo: Analisar as evidências científicas nacionais e internacionais disponíveis na literatura sobre os tipos de ações de judicialização da saúde. Método: Revisão integrativa, que selecionou estudos primários nas bases de dados PubMed, LILACS, Web of Science e Scopus, com os Descritores: decisões judiciais, judicialização da saúde, Saúde, Health, e a palavra-chave: Judicial Action. Resultados: Foram selecionados 30 estudos, sendo que no Brasil, a maioria se tratava de demandas judiciais por medicamentos e as demais por ações por erro médico, solicitação por vacinas, insumos para diabéticos, compostos alimentares, procedimento cirúrgico, exames, entre outras. Em estudos internacionais, foram encontradas ações por medicamentos, cobertura de benefícios e internação para tratamento psiquiátrico. Conclusão: Evidencia-se que o tipo de ação mais demandada foi o acesso ao medicamento a nível internacional. Ainda é mais perceptível a pouca discussão sobre essa temática, demonstrando que a judicialização de medicamentos pode indicar uma realidade característica do Brasil.

Descritores: Judicialização da Saúde; Decisões Judiciais; Saúde; Direito à Saúde; Política Pública de Saúde.

\section{RESUMEN}

Objetivo: Analizar las evidencias científicas nacionales e internacionales disponibles en la literatura sobre los tipos de acciones de judicialización de la salud. Método: Revisión integrativa, que seleccionó estudios primarios en las bases de datos PubMed, LILACS, Web of Science y Scopus, con los Descriptores: decisiones judiciales, judicialización de la salud, Salud, Health, y la palabra clave: Judicial Action. Resultados: Se seleccionaron 30 estudios, siendo que en Brasil, la mayoría se trataba de demandas judiciales por medicamentos y las demás por acciones por error médico, solicitud por vacunas, insumos para diabéticos, compuestos alimentarios, procedimiento quirúrgico, exámenes, entre otras. En estudios internacionales, se encontraron acciones por medicamentos, cobertura de beneficios e internación para tratamiento psiquiátrico. Conclusión: Se evidencia que el tipo de acción más demandada fue el acceso al medicamento a nivel internacional. Es aún más perceptible la poca discusión sobre esta temática, demostrando que la judicialización de medicamentos puede indicar una realidad característica de Brasil.

Descriptores: Judicialización de la Salud; Decisiones Judiciales; salud; Derecho a la Salud; Política Pública de Salud. 


\section{INTRODUCTION}

The fact that the Constitution of the Federative Republic of Brazil of $1988^{(1)}$, in its art. 196, describe that "health is the right of all and the duty of the State, guaranteed by social and economic policies aimed at reducing the risk of diseases, and universal and equal access to lawsuits and services for their promotion, protection and recovery", initiated a phenomenon that today is denominated "judicialization of health". This phenomenon is interpreted as the costing of medical procedures, medications, treatments, hospitalizations, orthoses and prostheses by judicial means.

In Brazil, judicialization of health began in the 1990s, with a high demand for lawsuits by the Judiciary to ensure that managers of public health services provided antiretroviral medications. For the organization and regulation of the distribution of these medicines, the Política Pública de Distribuição Gratuita de Medicamentos (Public Policy for the Free Distribution of Medicines) was established through Law 9313/1996, which ensured free and universal distribution of antiretroviral agents. It was hoped that, with the implementation of this law, there would be a decrease in judicial demands which did not occur ${ }^{(2,3)}$.

According to a study carried out by the Oswaldo Cruz Foundation - Fiocruz, "Judicialização da Política de Saúde nos Municípios Brasileiros: Um retrato nacional", a profile of the judicialization was presented in the city of São Paulo, following a pattern presented in the national survey, where $65 \%$ relating to medicinal products ${ }^{(4)}$. This issue is of great relevance to public administration, since the number of lawsuits that are filed with the Municipalities, States or the Federation to grant health treatment is high, resulting in one more expense to the public sector to effect such payments ${ }^{(5)}$.

During the last decades, judicialization of health has grown in some Latin American countries, such as Colombia which, with the enactment of Law 100/1993, reformulated the health system with the objective of providing universal coverage ${ }^{(6)}$. In Colombia, 640,000 lawsuits were filed by patients between 1999 and 2008 , one of the highest rates of judicialization of health. In Argentina, $72 \%$ of lawsuits are of individual demands for access to medicines ${ }^{(7)}$.

This study was carried out in the expectation of understanding aspects related to the increase of lawsuits for access to health services in Brazil; and, with this, to identify measures or alternatives to be adopted to reduce these lawsuits, as well as to identify gaps in knowledge on the subject.

\section{OBJECTIVE}

This study aims to analyze the national and international scientific evidence available in the literature on types of judicialization of health lawsuits.

\section{METHOD}

\section{Study design}

It is an integrative review, a method that aims to gather and synthesize the published studies, allowing general conclusions on a specific theme, and explanation of knowledge gaps ${ }^{(8)}$.

\section{Methodological framework and stages}

Evidence Based Practice is the methodological framework adopted. The study involved the following steps: elaboration of the research question, literature search of primary studies, data extraction, critical evaluation of the included primary studies, analysis and synthesis of results, and synthesis of the knowledge evidenced ${ }^{(9)}$.

\section{$1^{\text {st }}$ Stage: Elaboration of the research question}

The research question delimited for this study was: "What scientific evidence is available in the literature that analyze the types of judicialization of health lawsuits?".

\section{$2^{\text {nd }}$ Stage: Literature search of primary studies}

The search for primary studies was conducted in September 2017, in the following databases with free access at the institution under study: National Library of Medicine National Institutes of Health (PubMed), Latin American \& Caribbean Literature in Health Sciences (LILACS), Web of Science and Scopus.

The controlled descriptors were selected in the Descriptors in Health Science Descriptors (DeCS) and MeSH Database. Thus, to search in LILACS, the following descriptors were used: Judicial decisions, Health and Health's Judicialization. For Pubmed, Web of Science and Scopus were: Health and the uncontrolled delimited descriptor (keyword) was Judicial Action. In the Pubmed, Web of Science and Scopus databases, the terms were combined as follows: Health AND Judicial Action; and in LILACS: Judicial decisions OR Health's Judicialization AND Health.

\section{$3^{\text {rd }}$ Stage: Data extraction}

For data extraction, authors prepared and used a tool consisting of items related to identification of the article, objective and main results that answered the integrative review's guiding question.

\section{Criteria of inclusion and exclusion}

The inclusion criteria were complete articles in Portuguese, English and/or Spanish, published between 2007 and 2017, available in full that addressed the theme "health lawsuits involving access to all types of health services". Theses, dissertations, chapter books, theoretical articles, letter to the editor were excluded from the sample of this study.

Articles were searched between 2007 and 2017 in order to find the most recent publications related to the application of legislation, legal conduct and repercussions on the health service.

\section{$4^{\text {th }}$ Stage: Critical evaluation of the included primary studies}

Analyzes were performed independently by two reviewers, and the synthesis of the studies was presented in Charts 1 and 2 .

\section{$5^{\text {th }}$ Stage: Analysis and synthesis of results}

A descriptive analysis of each study was carried out, presenting a synthesis of the main results of these studies in Charts 1 and 2 . 


\section{$6^{\text {th }}$ Stage: Synthesis of the knowledge evidenced}

To evaluate the studies regarding Levels of Evidence, the classification was used in seven levels, being considered as level 1 (stronger) the evidence from a systematic review or meta-analysis of randomized clinical trials; level 2, evidence from well-delineated randomized clinical trials; level 3, evidence from well-delineated clinical trials without randomization; level 4, evidence from welldelineated cohort and case-control studies; level 5, evidence from a systematic review of descriptive and qualitative studies; level 6 , evidence from a single descriptive or qualitative study; and level 7 (weaker), evidence from expert opinion ${ }^{(10)}$.

\section{RESULTS}

In the first analysis of the 512 studies, after reading the title and abstract, articles that did not address lawsuits in health and duplicate articles were excluded $(n=414)$. In the second analysis, through reading in full ( $n=98), 53$ studies that did not portray the subject and 18 that were theoretical articles, book chapter, theses and dissertations were excluded. Three studies that did not appear in the selection by the databases were included through manual search, resulting in 30 articles selected for this study (Figure 1).

The years with the greatest number of publications were 2012, 2013, 2014 and 2015 with four publications in each year and in 2016 five studies were published. Regarding the language, 24 were published in Brazilian Portuguese, four in English and two in Spanish.

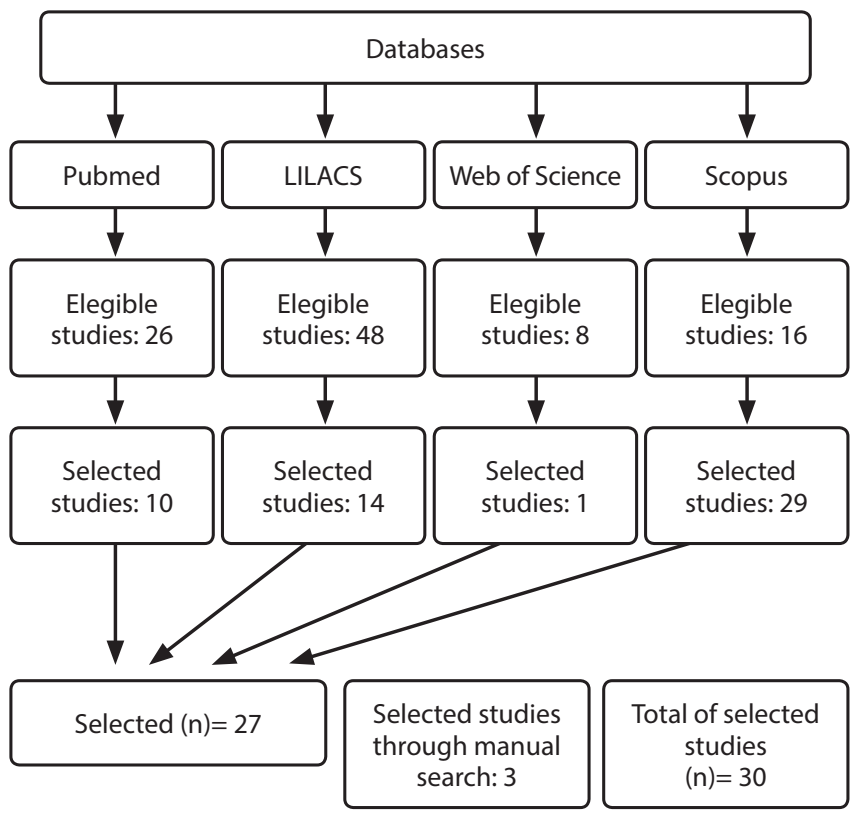

Figure 1 - Flowchart of primary studies selection included in the integrative review according to the databases, 2007-2017

In relation to the area of the authors, 15 were from Pharmacy, 14 Nursing, nine Medicine, six Law, three Economics, among others.

Regarding the method adopted by the studies, all were descriptive studies, with a quantitative approach (50\%), qualitative (16.7\%) and quantitative/qualitative (33.3\%), all with Level of Evidence 6.

Chart 1 - Synthesis of studies of lawsuits of demands for medications ( $n=21), 2007-2017$

\begin{tabular}{|c|c|c|}
\hline Article/Country & Objective & Main Results \\
\hline $\begin{array}{l}\text { (11) Biehl, J.; Socal, M.P.; Amon J.J. } \\
\text { The judicialization of health and the quest for state } \\
\text { accountability: Evidence from 1,262 lawsuits for access } \\
\text { to medicines in Southern Brazil } \\
\text { Health and human rights, 18(1), 209. (2016) } \\
\text { Brazil }\end{array}$ & $\begin{array}{l}\text { To evaluate the claims, offering } \\
\text { empirical evidence that myth } \\
\text { counters prevail and claim the } \\
\text { heterogeneity of the phenomenon } \\
\text { of judicialization. }\end{array}$ & $\begin{array}{l}\text { Most applicants are, in fact, poor and older } \\
\text { individuals who do not live in major metropolitan } \\
\text { areas. They also depend on the State to } \\
\text { provide their legal representation and most } \\
\text { of the requested medicines were already on } \\
\text { government forms. }\end{array}$ \\
\hline $\begin{array}{l}{ }^{(12)} \text { Cabral, l.; Rezende, L.F. } \\
\text { Análise das ações judiciais individuais para fornecimento } \\
\text { de medicamentos em São João da Boa Vista } \\
\text { Rev de Direito Sanitário. 2015; v. 16, n. 1, p. 59-77. Brazil }\end{array}$ & $\begin{array}{l}\text { To analyze individual lawsuits taken } \\
\text { to guarantee access to medicines in } \\
\text { the municipality of São João da Boa } \\
\text { Vista -SP. }\end{array}$ & $\begin{array}{l}\text { Most of lawsuits were filed by women } \\
\text { represented by private lawyers asking for } \\
\text { medication. }\end{array}$ \\
\hline $\begin{array}{l}{ }^{(13)} \text { Chieffi, A.L.; Barata, R.B. } \\
\text { Judicialização da política pública de assistência } \\
\text { farmacêutica e equidade } \\
\text { Cad de Saúde Pública. 2009; v. 25, p. 1839-1849 } \\
\text { Brazil }\end{array}$ & $\begin{array}{l}\text { To analyze the lawsuit used to } \\
\text { obtain medicines through the } \\
\text { Department of Health of São Paulo } \\
\text { State. }\end{array}$ & $\begin{array}{l}\text { Most of the litigation was filed by private lawyers, } \\
47 \% \text { had private network prescriptions and } \\
73 \% \text { of the cases were from patients with social } \\
\text { vulnerability. }\end{array}$ \\
\hline $\begin{array}{l}\text { (14) Chieffi, A.L.; Barata, R.C.B } \\
\text { Ações judiciais: estratégia da indústria farmacêutica } \\
\text { para introdução de novos medicamentos } \\
\text { Rev de Saúde Pública. 2010; v. 44, n. 3, p. 421-429. } \\
\text { Brazil }\end{array}$ & $\begin{array}{l}\text { To analyze the concentration in the } \\
\text { distribution of lawsuits according } \\
\text { to the medicine (manufacturer), } \\
\text { prescribing doctor and soliciting } \\
\text { attorney of the lawsuit. }\end{array}$ & $\begin{array}{l}1,309 \text { lawsuits were for acquisition of } 14 \\
\text { medications. Most cases were represented by } \\
\text { private lawyers and } 11 \text { lawyers accounted for } 613 \\
(47 \%) \text { cases. }\end{array}$ \\
\hline $\begin{array}{l}{ }^{(15)} \text { Coelho et al. } \\
\text { Variáveis jurídicas e de saúde no deferimento de } \\
\text { liminares por medicamentos em Minas Gerais } \\
\text { Rev de Saúde Pública. 2014; v. 48, n. 5, p. 808-816. } \\
\text { Brazil }\end{array}$ & $\begin{array}{l}\text { To investigate factors related to } \\
\text { the deferral of injunctions by } \\
\text { medications. }\end{array}$ & $\begin{array}{l}\text { Of the } 5,072 \text { lawsuits with injunctions, } 4,184 \\
\text { (82.5\%) were deferred. The medications paroxetine, } \\
\text { somatropin and ferrous sulfate were } 100 \% \text { deferred. } \\
\text { Escitalopram, diclofenac sodium and nortriptyline } \\
\text { obtained a reduction of less than } 54.0 \% \text {. }\end{array}$ \\
\hline
\end{tabular}




\begin{tabular}{|c|c|c|}
\hline Article/Country & Objective & Main Results \\
\hline $\begin{array}{l}\text { (16) Leitão et al. } \\
\text { Análise das demandas judiciais para aquisição de } \\
\text { medicamentos no estado da Paraíba } \\
\text { Saúde e Sociedade. 2016; v. 25, p. 800-807. } \\
\text { Brazil }\end{array}$ & $\begin{array}{l}\text { To describe medical-scientific and } \\
\text { health aspects of court injunctions } \\
\text { for the supply of medicines to the } \\
\text { Court of Paraíba against public } \\
\text { agents. }\end{array}$ & $\begin{array}{l}\text { Seventy-five claims were identified for different } \\
\text { medications. The most frequent were the } \\
\text { antineoplastic medications, followed by insulin } \\
\text { and angiotensin II antagonists. }\end{array}$ \\
\hline $\begin{array}{l}\text { (17) Lopes et al. } \\
\text { Medicamentos biológicos para o tratamento de psoríase } \\
\text { em sistema público de saúde } \\
\text { Rev de Saúde Pública. } 2014 \text { v. 48, n. 4, p. 651-661. } \\
\text { Brazil }\end{array}$ & $\begin{array}{l}\text { To analyze the access and profile of } \\
\text { use, by judicial means, of biological } \\
\text { medicines for the treatment of } \\
\text { psoriasis. }\end{array}$ & $\begin{array}{l}\text { There was access by injunction (59.5\%). } 66 \% \text { used } \\
\text { the biological medication for } 13 \text { months, } 26.6 \% \\
\text { abandoned treatment due to worsening of the } \\
\text { condition, } 20.5 \% \text { had adverse effects and } 13.8 \% \\
\text { did not have surgery, due to lack of efficacy. }\end{array}$ \\
\hline $\begin{array}{l}\text { (18) Machado et al } \\
\text { Judicialização do acesso a medicamentos no Estado de } \\
\text { Minas Gerais, Brasil } \\
\text { Rev de Saúde Pública. } 2011 \text {; v. 45, p. 590-598. } \\
\text { Brazil }\end{array}$ & $\begin{array}{l}\text { To analyze the profile of claimants } \\
\text { and medications pleaded in } \\
\text { lawsuits. }\end{array}$ & $\begin{array}{l}\text { Most of applicants were women, aged } 60 \text { or } \\
\text { over, retirees, pensioners and housewives. } \\
\text { The most requested medications were } \\
\text { immunosuppressants. }\end{array}$ \\
\hline $\begin{array}{l}\text { (19) Medeiros, M.; Diniz, D.; Doederlein, S. } \\
\text { A tese da judicialização da saúde pelas elites: os } \\
\text { medicamentos para mucopolissacaridose } \\
\text { Ciência \& Saúde Coletiva. } 2013 \text { v. 18, n. } 4 . \\
\text { Brazil }\end{array}$ & $\begin{array}{l}\text { Evaluating the hypothesis of } \\
\text { whether the judicialization of } \\
\text { medications for the treatment of } \\
\text { mucopolysaccharidoses in Brazil } \\
\text { would be a lawsuit of economic } \\
\text { elites. }\end{array}$ & $\begin{array}{l}\text { It is not possible to refute or corroborate the } \\
\text { thesis of judicialization by elites. There is no way } \\
\text { to say that judicialization is a matter of class. }\end{array}$ \\
\hline $\begin{array}{l}\text { Médicos, advogados e indústria farmacêutica na } \\
\text { judicialização da saúde em Minas Gerais, Brasil } \\
\text { Rev de Saúde Pública. 2012; v. 46, p. 784-790. } \\
\text { Brazil }\end{array}$ & $\begin{array}{l}\text { To describe the relationships } \\
\text { between prescriber, lawyer, and } \\
\text { pharmaceutical industry in lawsuits } \\
\text { against the State. }\end{array}$ & $\begin{array}{l}\text { Among lawsuits of a single office, } 43.6 \% \text { had } \\
\text { prescriptions from one doctor } X \text { for a medication } \\
\text { from a specific laboratory and that same } \\
\text { doctor was also the main prescriber of another } \\
\text { medication, in which they were represented by } \\
\text { two other offices. }\end{array}$ \\
\hline $\begin{array}{l}\text { (21) Pepe et al. } \\
\text { Characterization of lawsuits for the supply of } \\
\text { "essential" medicines in the State of Rio de Janeiro, } \\
\text { Brazil } \\
\text { Cad de Saúde Pública. 2010; v. 26, n. 3, p. 461-471. } \\
\text { Brazil }\end{array}$ & $\begin{array}{l}\text { To analyze individual lawsuits for } \\
\text { medication supply, considered } \\
\text { essential by the Court of Rio } \\
\text { de Janeiro State in the judicial } \\
\text { decisions of the Second Instance } \\
\text { in } 2006 .\end{array}$ & $\begin{array}{l}\text { Of the } 321 \text { medications identified in lawsuits, } 316 \\
\text { were present in the RENAME. }\end{array}$ \\
\hline $\begin{array}{l}\text { (22) Pereira, J.G.; Pepe, V.L.E. } \\
\text { Acesso a medicamentos por via judicial no Paraná: } \\
\text { aplicação de um modelo metodológico para análise e } \\
\text { monitoramento das demandas judiciais } \\
\text { Rev de Direito Sanitário. 2015; v. 15, n. 2, p. 30-45. } \\
\text { Brazil }\end{array}$ & $\begin{array}{l}\text { To apply the methodological model } \\
\text { developed in the analysis of the } \\
\text { individual judicial demands for } \\
\text { access to medicines in Paraná State. }\end{array}$ & $\begin{array}{l}\text { Results showed that the sources used in the study } \\
\text { were not enough to identify and quantify all } \\
\text { variables proposed in their dimensions, especially } \\
\text { some of the indicators of sociodemographic } \\
\text { characteristics. }\end{array}$ \\
\hline $\begin{array}{l}\text { (23) Portilla-Pinzón et al. Evaluation of prescriptions } \\
\text { authorized between } 2010 \text { and } 2011 \text { through judicial } \\
\text { protection in Bogotá } \\
\text { Rev de la Facultad de Medicina. 2016; v. 64, n. 4, p. } \\
679-685 \text {. } \\
\text { Colombia }\end{array}$ & $\begin{array}{l}\text { To evaluate the therapeutic } \\
\text { rationality of prescriptions } \\
\text { of medicines authorized by } \\
\text { guardianship in patients affiliated } \\
\text { to the General System of Social } \\
\text { Security in Health. }\end{array}$ & $\begin{array}{l}\text { In } 75.5 \% \text { of the cases, the medication was } \\
\text { correlated with the diagnosis and } 66 \% \text { of the } \\
\text { patients were exposed to risks of medication } \\
\text { interactions. }\end{array}$ \\
\hline $\begin{array}{l}\text { (24) Provin, M.P.; Leite, S.N.; Amaral, R.G. } \\
\text { Social inequalities in lawsuits for drugs } \\
\text { Brazilian Journal of Pharmaceutical Sciences 2013; v. } \\
\text { 49, n. 3, p. 465-474. } \\
\text { Brazil }\end{array}$ & $\begin{array}{l}\text { To characterize lawsuits that } \\
\text { requested medicines considering } \\
\text { the economic profile of their } \\
\text { impetrants. }\end{array}$ & $\begin{array}{l}\text { Residents of wealthier regions were responsible } \\
\text { for more frequent lawsuits. Lawsuit costs were } \\
\text { four times higher in the richer regions compared } \\
\text { to the poorer region. }\end{array}$ \\
\hline $\begin{array}{l}{ }^{(25)} \text { Ramos, K.A.; Ferreira, A.S.D. } \\
\text { Análise da demanda de medicamentos para uso off } \\
\text { label por meio de ações judiciais na Secretaria de Estado } \\
\text { de Saúde de Minas Gerais } \\
\text { Rev de Direito Sanitário. 2013; v. 14, n. 1, p. 98-121. } \\
\text { Brazil }\end{array}$ & $\begin{array}{l}\text { To investigate the occurrence of } \\
\text { a medication court application } \\
\text { for indications not approved by } \\
\text { the Agência Nacional de Vigilância } \\
\text { Sanitária (Brazilian National } \\
\text { Sanitary Surveillance Agency) } \\
\text { through lawsuits against Minas } \\
\text { Gerais State in } 2010 \text {. }\end{array}$ & $\begin{array}{l}212 \text { applications for off-label medications were } \\
\text { identified, of which } 46 \% \text { were not included in } \\
\text { pharmaceutical assistance programs. }\end{array}$ \\
\hline
\end{tabular}




\begin{tabular}{|c|c|c|}
\hline Article/Country & Objective & Main Results \\
\hline $\begin{array}{l}\text { (26) Sant'Ana et al. } \\
\text { Rational therapeutics: health-related elements in } \\
\text { lawsuits demanding medicines } \\
\text { Rev de Saúde Pública. } 2011 ; \text { v. 45, n. 4, p. 714-721. } \\
\text { Brazil }\end{array}$ & $\begin{array}{l}\text { To characterize the main } \\
\text { procedural, medical-scientific and } \\
\text { health elements that support the } \\
\text { decisions of the individual judicial } \\
\text { demands for medicines considered } \\
\text { essential. }\end{array}$ & $\begin{array}{l}\text { All lawsuits contained prescriptions and medical } \\
\text { certificates. The prescriptions were in discrepancy } \\
\text { with the legislation. There were no medical } \\
\text { examinations in any of the lawsuits and } 7.4 \% \\
\text { consisted of complementary tests. }\end{array}$ \\
\hline $\begin{array}{l}\text { (27) Silva, E.; de Almeida, K.C.; Pessoa, G.S.C } \\
\text { Análise do gasto com judicialização de medicamentos } \\
\text { no Distrito Federal, Brasil } \\
\text { Cadernos Ibero-Americanos de Direito Sanitário, 2017; } \\
6(1), 112-126 . \\
\text { Brazil }\end{array}$ & $\begin{array}{l}\text { To analyze the profile of public } \\
\text { health spending in the Federal } \\
\text { District with non-standard } \\
\text { medications occurs at this location. }\end{array}$ & $\begin{array}{l}\text { Total expenses were } 43.7 \text { million reais. Among the } \\
\text { medications with the highest expenditure, the } \\
\text { recombinant factor IX (haemophilia treatment) } \\
\text { was observed as the most responsible ( } 22.53 \%) \text {. }\end{array}$ \\
\hline $\begin{array}{l}{ }^{(28)} \text { Souza et al. } \\
\text { Direito à saúde no tribunal de justiça: demanda } \\
\text { por medicações em oncologia Rev da Rede de } \\
\text { Enfermagem do Nordeste. 2012; v. 13, n. } 4 . \\
\text { Brazil }\end{array}$ & $\begin{array}{l}\text { To describe the demand for the } \\
\text { right to health in the Court of Mato } \\
\text { Grosso State on medicines for } \\
\text { people with cancer. }\end{array}$ & $\begin{array}{l}\text { There were } 25 \text { lawsuits for cancer medications, } \\
32 \% \text { cited the amount of medicine needed, } 60 \% \\
\text { determined the medication delivery period, } \\
16 \% \text { brought the dosage and } 4 \% \text { contained the } \\
\text { deadline to meet the demand determined by the } \\
\text { judge. }\end{array}$ \\
\hline $\begin{array}{l}\text { (29) Stamford, A.; Cavalcanti, M. } \\
\text { Decisões judiciais sobre acesso aos medicamentos em } \\
\text { Pernambuco } \\
\text { Rev de Saúde Pública. 2012; v. 46, p. 791-799. } \\
\text { Brazil }\end{array}$ & $\begin{array}{l}\text { To analyze the decisions of the legal } \\
\text { system on access of the population } \\
\text { to medicines in the Sistema Único } \\
\text { de Saúde (Brazilian Unified Health) } \\
\text { System by judicial means regarding } \\
\text { decision criteria and possible } \\
\text { political and economic pressures. }\end{array}$ & $\begin{array}{l}\text { The Federal Constitution and medical } \\
\text { prescription were identified as a decision criterion } \\
\text { in lawsuits. }\end{array}$ \\
\hline $\begin{array}{l}\text { (30) Vieira, F.S.; Zucchi, P. } \\
\text { Distorções causadas pelas ações judiciais à política de } \\
\text { medicamentos no Brasil } \\
\text { Rev de Saúde Pública. 2007; v. 41, p. 214-222. } \\
\text { Brazil }\end{array}$ & $\begin{array}{l}\text { To describe the effects of lawsuits } \\
\text { that requires the supply of } \\
\text { medications, in relation to aspects } \\
\text { of the national medication policy. }\end{array}$ & $\begin{array}{l}\text { The total expense was of } 876 \text { thousand reais } \\
\text { (Brazilian currency) for items that are not part of } \\
\text { the Municipal Relation of Essential Medicines. Of } \\
\text { the total expenditure, } 75 \% \text { were allocated to the } \\
\text { acquisition of antineoplastic agents and two of } \\
\text { these medications were not registered in Brazil. }\end{array}$ \\
\hline $\begin{array}{l}\text { (31) Wang et al. } \\
\text { Os impactos da judicialização da saúde no município de } \\
\text { São Paulo: gasto público e organização federativa } \\
\text { Rev de Administração Pública-RAP. 2014; v. 48, n. } 5 \text {. } \\
\text { Brazil }\end{array}$ & $\begin{array}{l}\text { To analyze the impact of health } \\
\text { judicialization in the city of São } \\
\text { Paulo. }\end{array}$ & $\begin{array}{l}\text { Approximately } 55 \% \text { of health care expenditures } \\
\text { are spent on the supply of State or Union } \\
\text { medicines and } 45 \% \text { on non-contemplated SUS } \\
\text { (Unified Health System) treatments. }\end{array}$ \\
\hline
\end{tabular}

Chart 2 - Synthesis of studies of lawsuits demands of surgical procedures, hospitalization in the Intensive Care Unit, medical error, consultations and examinations, surgical materials, home hospitalization, among others $(n=9), 2007-2017$

\begin{tabular}{|c|c|c|}
\hline Article/Country & Objective & Main Results \\
\hline $\begin{array}{l}{ }^{(32)} \text { Arruda } \\
\text { Análise sobre a judicialização da saúde no estado } \\
\text { de mato grosso no período de 2011-2012 } \\
\text { Cad Íbero-Americanos de Direito Sanitário. } \\
2017 ; \text { v. } 6, \text { n. 1, p. 86-111. } \\
\text { Brazil }\end{array}$ & $\begin{array}{l}\text { To understand the phenomenon of the } \\
\text { judicialization of access to public health in Mato } \\
\text { Grosso State. }\end{array}$ & $\begin{array}{l}\text { Population is more aware of their rights and } \\
\text { requires it through judicial decisions. }\end{array}$ \\
\hline $\begin{array}{l}{ }^{(33)} \text { Asensi et al. } \\
\text { Judicialização, direito à saúde e prevenção } \\
\text { Rev Eletron de Comun Inf Inov Saúde. } 2015 \\
\text { jan-mar; 9(1). } \\
\text { Brazil }\end{array}$ & $\begin{array}{l}\text { To analyze the practice of preventive medicine, } \\
\text { with regard to vaccination, resulting from the } \\
\text { intervention of the Judiciary. }\end{array}$ & $\begin{array}{l}110 \text { cases were identified, } 25 \text { of which were } \\
\text { about the supply of vaccines to specific } \\
\text { individuals. They emphasized that they did } \\
\text { not find lawsuits that sought to force the } \\
\text { State to act in a preventive way. }\end{array}$ \\
\hline $\begin{array}{l}{ }^{(34)} \text { Gomes } \\
\text { O Erro médico sob o olhar do Judiciário: uma } \\
\text { investigação no Tribunal de Justiça do Distrito } \\
\text { Federal e Territórios } \\
\text { Cad. Íbero-Americanos de Direito Sanitário. } \\
\text { 2017; v. 6, n. 1, p. 72-85. } \\
\text { Brazil }\end{array}$ & $\begin{array}{l}\text { To know judicial decisions from the Second } \\
\text { Instance on medical errors. }\end{array}$ & $\begin{array}{l}\text { It resulted in } 202 \text { civil cases, being the } \\
\text { specialty with the largest number of cases in } \\
\text { Gynecology/Obstetrics. }\end{array}$ \\
\hline
\end{tabular}




\begin{tabular}{|c|c|c|}
\hline Article/Country & Objective & Main Results \\
\hline $\begin{array}{l}{ }^{(35)} \text { Gomes et al. } \\
\text { Acesso aos procedimentos de média e alta } \\
\text { complexidade no Sistema Único de Saúde: uma } \\
\text { questão de judicialização Cad de Saúde Pública. } \\
2014 ; \text { v. 30, p. 31-43. } \\
\text { Brazil }\end{array}$ & $\begin{array}{l}\text { To investigate lawsuits for access to outpatient } \\
\text { and hospital procedures in Minas Gerais State, } \\
\text { Brazil, from } 1999 \text { to } 2009 \text {. }\end{array}$ & $\begin{array}{l}\text { The most requested procedures were } \\
\text { hospitalizations in common beds, Intensive } \\
\text { Care Unit and surgeries of the circulatory } \\
\text { system. }\end{array}$ \\
\hline $\begin{array}{l}{ }^{(36)} \text { Gotlieb, V.; Yavich, N.; Báscolo, E. } \\
\text { Litigio judicial y el derecho a la salud en } \\
\text { Argentina } \\
\text { Cad de Saúde Pública. 2016. v. 32, n. } 1 \\
\text { Argentina }\end{array}$ & $\begin{array}{l}\text { To explore the profile of litigation for access to } \\
\text { health care processed before the Supreme Court } \\
\text { of Argentina. }\end{array}$ & $\begin{array}{l}\text { A predominance of lawsuits was observed } \\
\text { by individual applicants (88\%) and private } \\
\text { insurance applicants (64\%). } 87 \% \text { claimed } \\
\text { coverage of a medical service. }\end{array}$ \\
\hline $\begin{array}{l}\text { (37) Massaú, G.C.; Bainy, A.K. } \\
\text { O Impacto da judicialização da saúde na } \\
\text { comarca de Pelotas } \\
\text { Rev de Direito Sanitário. 2015; v. 15, n. 2, p. } \\
46-65 \\
\text { Brazil }\end{array}$ & $\begin{array}{l}\text { To unveil the impact of health judicialization in } \\
\text { Pelotas District. }\end{array}$ & $\begin{array}{l}\text { The budget deficit of the Municipality of } \\
\text { Pelotas is of the same value of the judicial } \\
\text { demands, that is, the budgetary demands } \\
\text { exceeded 2,699,939.44 reais due to the } \\
\text { judicial decisions. }\end{array}$ \\
\hline $\begin{array}{l}\text { (38) Nunes, C.F.O.; Ramos Junior, A.N. } \\
\text { Judicialização do direito à saúde na região } \\
\text { Nordeste, Brasil: dimensões e desafios } \\
\text { Cad. Saúde Colet., (Rio J.), 2016. 24(2), 192-199. } \\
\text { Brazil }\end{array}$ & $\begin{array}{l}\text { To characterize the judicialization of the right to } \\
\text { health in Ceará State, to size its magnitude and to } \\
\text { describe the profile of the subjects, pathologies } \\
\text { and objects demanded. }\end{array}$ & $\begin{array}{l}74 \% \text { of requests were for medicines, the } \\
\text { median age of the authors was } 57.8 \text { years and } \\
68 \% \text { were represented by private lawyers. } \\
76 \% \text { of the prescriptions came from the } \\
\text { public network and the most requested } \\
\text { goods were Mabthera, Spiriva, Lantus and } \\
\text { other supplies for diabetes. }\end{array}$ \\
\hline $\begin{array}{l}\text { (39) Petean et al. } \\
\text { Direito à saúde: demanda por suplementos no } \\
\text { Tribunal de Justiça } \\
\text { Rev Eletr de Enfermagem. 2012; v. 14, n. 1, p. } \\
68-76 . \\
\text { Brazil }\end{array}$ & $\begin{array}{l}\text { To know the origin, the motive, the object, the } \\
\text { plaintiff subject and the resolution of the judicial } \\
\text { decisions. }\end{array}$ & $\begin{array}{l}\text { Lawsuits were mostly requests for food } \\
\text { compounds from glycemic control tapes. } \\
\text { All medical prescriptions requested for } \\
\text { trademarks and pediatric food allergy was the } \\
\text { main reason for the lawsuit. }\end{array}$ \\
\hline $\begin{array}{l}\text { (40) Salvatori, R.T.; Ventura. C.A.A. } \\
\text { Internamentos não voluntários civis por razão de } \\
\text { transtorno psíquico na Catalunha: uma análise } \\
\text { das decisões judiciais à luz da bioética } \\
\text { Physis: Rev de Saúde Coletiva. 2013; v. 23, p. } \\
\text { 531-552. } \\
\text { Spain }\end{array}$ & $\begin{array}{l}\text { To investigate the jurisprudence of Provincial } \\
\text { Hearings of the Autonomous Region of } \\
\text { Catalonia, Spain, on the requests for non- } \\
\text { voluntary hospitalization of persons with psychic } \\
\text { disorders. }\end{array}$ & $\begin{array}{l}\text { Fifteen central ideas were identified in judicial } \\
\text { decisions, analyzed according to principles } \\
\text { of mainstream bioethics. The benevolent } \\
\text { principle of non-voluntary hospitalization } \\
\text { seems to prevail over all others. }\end{array}$ \\
\hline
\end{tabular}

Twenty-seven studies were found in Brazil, where medication lawsuits were predominant (74\%). Afterwards, there were studies (26\%) that described requests for surgical procedures, hospitalization at the Intensive Care Unit, medical error, consultations and exams, home care, surgeries, food supplements, orthoses and prostheses, hospitalization for psychiatric treatment, SPA hospitalization, request for vaccines, supplies for diabetics, home hospitalization, demand for hospital transportation, among others.

In international studies, lawsuits were found for medications in Colombia $(n=1)$, benefit coverage in Argentina $(n=1)$ and hospitalization for psychiatric treatment in Spain $(n=1)$.

Synthesis of studies were categorized into lawsuits requiring medication (Chart 1) and lawsuits for surgical procedures, hospitalization at the Intensive Care Unit, medical error, consultations and examinations, surgical materials, home hospitalization, among others (Chart 2). Synthesis of studies is presented in the Charts in alphabetical order of authors.

\section{DISCUSSION}

The public health system in Brazil comprises a set of lawsuits and services, however, it is noted that most of the studies published on the types of judicialization of health lawsuits deal with access to medicines.

Lawsuits for medicines have been taking place even after the creation in 1996 of public policy, which promises the free and universal dispensation of medications. From this perspective, it is worth mentioning that lawsuits also occur with medications contained in the Relação Nacional de Medicamentos Essenciais (RENAME - National Relation of Essential Medicines). This practice needs to be reviewed in light of the fact that most of lawsuits are accompanied by a medical professionals' ${ }^{\prime(3)}$.

In this sense, 21 articles involved access to medications ${ }^{(11-31)}$, in which six articles were required medications, such as Adalimumab and Etanercept ${ }^{\left(14^{\prime} 15^{\prime} 17^{\prime} 18^{\prime} 20^{\prime} 22\right)}$, indicated for the treatment 
of rheumatoid arthritis. Four articles demanded medications, such as Infliximabe ${ }^{\left(14^{\prime} 17^{\prime 2} 0^{\prime 22}\right)}$, also recommended for rheumatoid arthritis. Rituximab ${ }^{\left(16^{2} 22^{2} 25^{2} 28\right)}$ was indicated for treatment of nonHodgkin's lymphoma. These medicines are present in RENAME, but the population has been finding difficulties in accessing these medicines, in which the pharmaceutical assistance policy presents flaws in the programming, acquisition and distribution of medications ${ }^{(18)}$.

On the other hand, requests for non-standard and high-cost medications can be influenced by the pharmaceutical industry in partnership with prescribing doctors. And the irrational and unnecessary use of new medications, often without scientific evidence, aiming at the future standardization of this technology, and may be a factor that promotes an increase in the demand for medicines and high expenses with judicialization ${ }^{(41)}$.

In order to standardize a new medication, it is necessary, in addition to the safety factors, effectiveness and effectiveness, that these are the best option in relation to the cost, because thus more people would have access ${ }^{(42)}$.

Judicialization of health does not only include access to medicines. One of the articles found in this review refers to civil and criminal cases on medical error, in which the specialty with the greatest number of cases was Gynecology/Obstetrics ${ }^{(34)}$. Braga, Vieira and Martins ${ }^{(43)}$ performed a study in which there was a tendency to increase lawsuits in the ophthalmological area, and a predominance of lawsuits in surgical ophthalmologic procedures.

In a recent study in the United States, medical errors are classified as the third leading cause of death, where data on mortality in the country were analyzed for eight years, noting that more than 250,000 deaths per year are attributed to errors ${ }^{(44)}$. However, the study detected little scientific publication on the judicialization of medical error.

It is noteworthy that the types of lawsuits outside Brazil were demands on coverage of benefits in Argentina, medicines, such as antiepileptics in Colombia and hospitalization for psychiatric treatment in Spain. Given the lack of world literature on the proposed theme, it is questioned whether health judicialization is a specific problem of greater transparency in Brazilian public health, or if the scarce publication is due to scientific omission, considering that nations worldwide are subject to such structuralpolitical complications.

\section{Study limitations}

The limitation of this study was that the selected databases were only those accessible to researchers of this study, and the extension of the search in other paid databases could contemplate other types of studies in other realities.

\section{Contributions for the area of Public Policy}

The study contributes to the characterization of health judicial demands, enabling public managers to detect failures in distribution and acquisition of medicines, which can avoid lawsuits for standardized medications. On the other hand, the study boosts reflection on the scientific evidence of requests before lawsuits are judged through consultations with doctors, in order to avoid prescriptions of non-standardized technologies, especially in medicines, and can thus reduce the quantity of lawsuits in health.

\section{CONCLUSION}

This integrative review found that access to the medication was the most obvious type of lawsuit. However, even with the increase in judicialization of health, what resulted in the main limitation of this study was the scarcity of literature on the subject. At the international level, the lack of discussion on the subject was even more evident, revealing that the judicialization of access to medicines may indicate a reality that is characteristic of Brazil. Thus, it is evident the need to produce new studies on the reason for requesting standardized medications through lawsuits. This indicates possible management failures in the acquisition and distribution of these medications and the reason for the medical prescription of non-standard medications, which may indicate a presumed lack of knowledge of prescribers about medications present in the SUS lists. This fact can also indicate the induction of prescription by the pharmaceutical industry, aiming at the inclusion of new medications.

\section{REFERENCES}

1. Presidência da República (BR), Casa Civil, Subchefia para Assuntos Jurídicos Constituição da República Federativa do Brasil, 1988 [Internet]. Diário Oficial da União: República Federativa do Brasil; 1998 [cited 2019 Mar 12]. Oct 5. Seção 1: [about 35 screens]. Available from: http:// www.planalto.gov.br/ccivil_03/Constituicao/Constituicao.htm

2. Presidência da República (BR), Casa Civil, Subchefia para Assuntos Jurídicos. Lei n 9.313, de 13 de novembro de 1996. Dispõe sobre a distribuição gratuita de medicamentos aos portadores do HIV e doentes de AIDS [Internet]. Diário Oficial da União: República Federativa do Brasil; 1996 [cited 2019 Mar 12]. Nov 11, Seção 1: [about 2 screens]. Available from: http://www.planalto.gov.br/ccivil_03/LEIS/L9313.htm

3. Oliveira MRM, Delduque MC, Sousa MF, Mendonça AVM. Mediation : a way to disjudialize health. Temp Act Saúde Col [Internet]. 2016 [cited 2019 Mar 12];10(1):169-77. Available from: http://dx.doi.org/10.18569/tempus.v10i1.1860 Portuguese.

4. Fundação Oswaldo Cruz (FioCruz). Judicialização da Política de Saúde nos Municípios Brasileiros: um retrato nacional [Internet] Rio de Janeiro: FioCruz; 2018 [cited 2019 Mar 12]. Available from: http://amazonia.fiocruz.br/index.php/2018/01/25/ estudo-traca-panorama-da-judicializacao-da-saude-no-brasil/

5. Zago B. Swiech LM, Bonamigo EL, Schlemper JBR. [Bioethical Aspects of Health Judicialization for drugs in 13 Municipalities in the Midwest of Santa Catarina, Brazil]. Act Bioethica [Internet]. 2016 [cited 2019 Mar 12];22(2):293-302. Available from: http://dx.doi.org/10.4067/ 


\section{S1726-569X2016000200016}

6. Lamprea E. Colombia's Right-to-Health Litigation in a Context of Health Care Reform (February 15, 2013). The Right to Health at the Public/ Private Divide: A Global Comparative Study. Gross A, Flood C, editors. Cambridge University Press, Forthcoming. Available at SSRN: https:// ssrn.com/abstract $=2255658$

7. Yamin AE, Siri G. Litigating health rights: Can courts bring more justice to health? Vol. 3. Harvard University Press, 2011.

8. Soares CB, Hoga LA, Peduzzi M, Sangaleti C, YonekuraT, Silva DR. Integrative review: Concepts and methods used in Nursing. Rev Esc Enferm USP [Internet]. 2014 [cited 2019 Mar 12]; 48(2):329-39. Available from: http://dx.doi.org/10.1590/S0080-6234201400002000020

9. Mendes KDS, Silveira RCCP, Galvão CM. [Integrative literature review: a research method to incorporate evidence in health care and nursing]. Texto Contexto Enferm [Internet]. 2008 [cited 2019 Mar 12];17(4):758-64. Available from: http://dx.doi.org/10.1590/ S0104-07072008000400018 Portuguese.

10. Melnyk BM, Fineout-Overholt E. Evidence-based practice in nursing \& healthcare: a guide to best practice. Philadelphia: Lippincott Williams \&Wilkins; 2011. Chapter 1: Making the case evidence-basead practice and cultivating a spirit of inquiry, p. 3-24.

11. Biehl J, Socal MP, Amon JJ. The judicialization of health and the quest for state accountability: evidence from 1,262 lawsuits for access to medicines in southern Brazil. Health Hum Rights [Internet]. 2016 [cited 2019 Mar 12];18(1):209-20. Available from: https://pdfs.semanticscholar.org/b787/0d87ead2460a5cb8c41059e90bf7236a271e. pdf?_ga=2.169565409.1195865572.1552323956-1942654150.1552323956

12. Cabral I, Rezende LF. [Analysis of individual lawsuits on supplying medication in São João da Boa Vista, São Paulo, Brazil]. R Dir Sanit [Internet]. 2015 [cited 2019 Mar 12];16(1):59-77. Available from: https://doi.org/10.11606/issn.2316-9044.v16i1p59-77 Portuguese.

13. Chieffi AL, Barata RB. ["Judicialization" of public health policy for distribution of medicines]. Cad Saúde Pública [Internet]. 2009 [cited 2019 Mar 12];25(8):1839-49. Available from: http://dx.doi.org/10.1590/S0102-311X2009000800020 Portuguese.

14. Chieffi AL, Barata RCB. Legal suits: pharmaceutical industry strategies to introduce new drugs in the brazilian public healthcare system. Rev Saúde Pública [Internet]. 2010 [cited 2019 Mar 12];44(3). Available from: http://dx.doi.org/10.1590/S0034-89102010000300005

15. Coelho TL, Ferré F, Neto OHC, Assis AF, Cherchiglia ML, Andrade EIG. Legal and health variations in drug litigation injunctions granted in Minas Gerais. Rev Saúde Pública [Internet]. 2014 [cited 2019 Mar 12];48(5):808-16. Available from: http://dx.doi.org/10.1590/ S0034-8910.2014048005286

16. Leitão LCA, Silva PCDD, Simões AEO, Barbosa IC, Pinto MEB, Simões MODS. Analysis of medicine procurement lawsuits in the state of Paraíba, Brazil. Saúde Soc [Internet]. 2016 [cited 2019 Mar 12];25(3):801-8. Available from: http://dx.doi.org/10.1590/S0104-12902016153819

17. Lopes LC, Nascimento SMS, Camargo IA, Barberato-Filho S, Del Fiol FDS, Osorio-de-Castro CGS. Biological drugs for the treatment of psoriasis in a public health system. Rev Saúde Pública [Internet]. 2014 [cited 2019 Mar 12];48(4):651-61. Available from: http://dx.doi. org/10.1590/S0034-8910.2014048005109

18. Machado MAA, Acurcio FDA, Brandão CMR, Faleiros DR, Guerra Jr AA, Cherchiglia ML et al. Judicialization of access to medicines in minas gerais state, southeastern brazil. Rev de Saúde Pública [Internet]. 2011 [cited 2019 Mar 12];45(3). Available from: http://dx.doi.org/10.1590/ S0034-89102011005000015

19. Medeiros M, Diniz D, Doederlein S, Ida V. [The thesis of judicialization of health care by the elites: medication for mucopolysaccharidosis]. Ciência \& Saúde Coletiva [Internet]. 2013 [cited 2019 Mar 12];18(4):1089-98. Available from: http://dx.doi.org/10.1590/ S1413-81232013000400022 Portuguese.

20. Neto OHC, Acurcio FA, Machado MAA, Ferré F, Barbosa FLV, Cherchiglia ML, et al. Doctors, lawyers and pharmaceutical industry on health lawsuits in Minas Gerais, Southeastern Brazil. Rev Saúde Pública [Internet]. 2012 [cited 2019 Mar 12];46(5):784-90. Available from: http:// dx.doi.org/10.1590/S0034-89102012000500004

21. Pepe VLE, Ventura M, Sant'ana JMB, Figueiredo TA, Souza VDRD, Simas L, Osorio-de-Castro CGS. [Characterization of lawsuits for the supply of "essential" medicines in the state of rio de janeiro, brazil]. Cad Saúde Pública [Internet]. 2010 [cited 2019 Mar 12];26(3):461-71. Available from: http://dx.doi.org/10.1590/S0102-311X2010000300004 Portuguese.

22. Pereira JG, Pepe VLE. [Judicial access to medicine in paraná: applying a methodological model for lawsuit analysis and monitoring]. R Dir Sanit [Internet]. 2014 [cited 2019 Mar 12];15(2):30-45. Available from: https://doi.org/10.11606/issn.2316-9044.v15i2p30-45 Portuguese.

23. Portilla-Pinzón A, López JJ, Montoya-Cañon M, Machado-Alba JE. [Evaluation of prescriptions authorized between 2010 and 2011 through judicial protection in Bogotá]. Rev Fac Med [Internet]. 2016 [cited 2019 Mar 12];64(4):679-85. Available from: http://dx.doi.org/10.15446/ revfacmed.v64n4.53574 Spanish.

24. Provin MP, Leite SN, Amaral RG. Social inequalities in lawsuits for drugs. Braz J Pharm Sci [Internet]. 2013 [cited 2019 Mar 12];49(3):465-74. Available from: http://dx.doi.org/10.1590/S1984-82502013000300008

25. Ramos KA, Ferreira ASD. [Analysis of the demand for medicines for off label use through lawsuits in the state health secretariat of minas gerais]. R Dir Sanit [Internet]. 2013 [cited 2019 Mar 12];14(1):98-121. Available from: https://doi.org/10.11606/issn.2316-9044.v14i1 p98-121 Portuguese.

26. Sant'ana JMB, Pepe VLE, Figueiredo TA, Osorio-de-Castro CGS, Ventura M. Rational therapeutics: health-related elements in lawsuits demanding medicines. Rev Saúde Pública [Internet]. 2011 [cited 2019 Mar 12];45(4). Available from: http://dx.doi.org/10.1590/ S0034-89102011005000042 
27. Silva, EM, de Almeida, KC, Pessoa, GSC. [Analysis of drug expenditure with judicialization in the federal district, brazil]. Cad Ibero-Amer Dir Sanit [Internet]. 2017 [cited 2019 Mar 12];6(1):112-26. Available from: http://dx.doi.org/10.17566/ciads.v6i1.358 Portuguese.

28. Souza ÍP, Bellato R, Araújo LFS, Almeida KBB, Nepomuceno MAS, Mufato LF. [Right to health in the court of justice: demand for oncology drugs]. Rev RENE [Internet]. 2012 [cited 2019 Mar 12];13(4):919-28. Available from: https://www.redalyc.org/pdf/3240/324027983022.pdf Portuguese.

29. Stamford A, Cavalcanti M. Legal decisions on access to medicines in pernambuco, northeastern brazil. Rev Saúde Pública [Internet]. 2012 [cited 2019 Mar 12];46(5). Available from: http://dx.doi.org/10.1590/S0034-89102012000500005

30. Vieira FS, Zucchi P. Distortions to national drug policy caused by lawsuits in brazil. Rev Saúde Pública [Internet]. 2007 [cited 2019 Mar 12];41(2). Available from: http://dx.doi.org/10.1590/S0034-89102007000200007

31. Wang DWL, Vasconcelos NP, Oliveira VE, Terrazas FV. [The impacts of health care judicialization in the city of Sao Paulo: public expenditure and federal organization]. Rev Adm Pública [Internet]. 2014 [cited 2019 Mar 12];48(5):1191-1206. Available from: http://dx.doi. org/10.1590/0034-76121666 Portuguese.

32. Arruda SC. [Analysis of the legalization of health in the state of mato grosso in the period 2011-2012]. Cad Íbero Amer Dir Sanit [Internet]. 2017 [cited 2019 Mar 12];6(1):86-111. Available from: http://dx.doi.org/10.17566/ciads.v6i1.308 Portuguese

33. Asensi FD, Aidar A, Ramos F, Pinheiro R. [Judicialization, right to health and prevention]. Rev Eletron de Comun Inf Inov Saúde [Internet]. 2015 [cited 2019 Mar 12];9(1). Available from: http://dx.doi.org/10.29397/reciis.v9i1.935 Portuguese.

34. Gomes TR. [The medical error under the eyes of the Judiciary: an investigation at the court of justice of federal district and territories]. Cad Íbero-Amer Dir Sanit [Internet]. 2017 [cited 2019 Mar 12];6(1):72-85. Available from: http://dx.doi.org/10.17566/ciads.v6i1.362 Portuguese.

35. Gomes FDFC, Cherchiglia ML, Machado CD, Santos VCD, Acurcio FDA, Andrade EIG. [Access to medium and high-complexity procedures in the brazilian unified national health system: a matter of judicialization]. Cad Saúde Pública [Internet]. 2014 [cited 2019 Mar 12];30(1):31-43. Available from: http://dx.doi.org/10.1590/0102-311X00176812 Portuguese.

36. Gotlieb, V, Yavich N, Báscolo E. [Litigation and the right to health in argentina]. Cad Saúde Pública [Internet]. 2016 [cited 2019 Mar 12];32(1):e00121114. Available from: http://dx.doi.org/10.1590/0102-311X00121114 Spanish.

37. Massaú GC, Bainy AK. [Impact of healthcare legal enforcement in pelotas district]. R Dir Sanit [Internet]. 2015 [cited 2019 Mar 12];15(2):4665. Available from: https://doi.org/10.11606/issn.2316-9044.v15i2p46-65 Portuguese.

38. Nunes, C. F. O., \& Ramos Jr, A. N. [Judicialization of the right to health in the brazilian northeastern region: dimensions and challenges]. Cad Saúde Colet [Internet]. 2016 [cited 2019 Mar 12];24(2):192-9. Available from: http://dx.doi.org/10.1590/1414-462X201600020070 Portuguese.

39. Petean E, Araújo LFS, Bellato R, Wunsch CG, Mufato LF, Nepomuceno MAS. [The right to health: a demand for supplements in the court of justice]. Rev Eletr Enf [Internet]. 2012 [cited 2019 Mar 12];14(1):68-76. Available from: https://doi.org/10.5216/ree.v14i1.12369 Portuguese.

40. Salvatori RT, Ventura CAA. [Civil non-voluntary hospitalizations by reason of mental disorders at Catalonia: an analysis of judicial decisions in light of bioethics]. Physis [Internet]. 2013 [cited 2019 Mar 12];23(2):531-552. Available from: http://dx.doi.org/10.1590/S010373312013000200011 Portuguese.

41. Soares, JCRS, Deprá AS. [Dangerous liaisons: the pharmaceutical industry, patients associations and the legal battles for access to medicines]. Physis [Internet]. 2012 [cited 2019 Mar 12]; Available from: http://dx.doi.org/10.1590/S0103-73312012000100017 Portuguese.

42. Medici AC. Judicialização, integralidade e financiamento da saúde. Diagn Trat [Internet]. 2010 [cited 2019 Mar 12];15(2):81-87. Available from: https://www.researchgate.net/publication/280612164_Judicializacao_Integralidade_e_Financiamento_da_Saude_no_Brasil Portuguese.

43. Braga IFA, Vieira KO, Martins TGS. Civil liability of the ophthalmologist in the são paulo court of appeals. Einstein [Internet]. 2017 [cited 2019 Mar 12];15(1):40-4. Available from: http://dx.doi.org/10.1590/S1679-45082017AO3781

44. Makary MA, Daniel M. Medical Error - the third leading cause of death in the US. BMJ [Internet]. 2016 [cited 2019 Mar 12];353:i2139. Available from: http://dx.doi.org/10.1136/bmj.i2139 